Tetiana Borysova,

D.Sc., Associate Professor, Ternopil National Economic University, Ukraine

Grygorii Monastyrskyi,

D.Sc., Professor, Ternopil National Economic University, Ukraine

Anetta Zielinska,

D.Sc., Professor, Wroclaw University of Economics, Poland

Mariusz Barczak,

Ph.D., Associate Professor, University of Economy in Bydgoszcz, Poland

\title{
INNOVATION ACTIVITY DEVELOPMENT OF URBAN PUBLIC TRANSPORT SERVICE PROVIDERS: MULTIFACTOR ECONOMIC AND MATHEMATICAL MODEL
}

\begin{abstract}
Systematization literary sources and approaches for solving the problem of ecologists of «smart» city indicates that among factors that probably can affect the innovativeness of Ukrainian providers of urban public transport services have been used environmental factor, marketing expenses, financial potential, wear rate, level of quality of service, level of management skills, market share, tariff for passenger transportation. The purpose of the study is to identify the ways to improve the innovativeness of urban public transport service providers of the regional centres of Ukraine. The main aim of the research is to estimate the impact of several factor variables on the resulting attribute used multivariate regression analysis, which provided an adequate model. A significant contribution to the development of the theory and methodology of management of urban public transport enterprises were made by Nunes, Krasnyanskiy, Umpleby, Walters, Huang, Morchadze. The results of the evaluation of the innovativeness of Ukrainian providers of urban public transport services carried out based on the mathematical multifactor model are presented in the article. In January-March 2018, the authors initiated a study on the current state of urban public transport in regional Ukrainian cities. Methodological tools of the research were multivariate correlation-regression analysis and survey (the requests for public information were submitted by the Law of Ukraine "On Access to Public Information» to all city councils of Ukraine's regions except temporarily occupied territories). The study included a survey of 20 experts (marketers and experienced managers of transport companies) to determine weighting factors and the level of innovativeness through questionnaires. The expert evaluation was carried out using the marks method. The research has shown that the size of the innovativeness of providers of public transport services can be successfully interpreted through functional and statistical dependencies, which reflect the general and individual laws of the development of such entities using multi-factor mathematical models. The econometric model was tested for the adequacy with the Fisher criterion and the presence of autocorrelation. The research empirically confirms and theoretically proves that such controllable factors are an environmental factor, financial potential, level of quality of service, level of management skills, the tariff for passenger transportation. The model can be used to predict the influence of controllable factors at the level of the innovativeness of providers of urban public transport services. The results of the research can be useful for scientific and practical workers, teachers, students of higher educational establishments.
\end{abstract}

Keywords: econometric model, factors of innovativeness, innovativeness, urban transport, ecologists.

Introduction. The analysis of empirical data on the development of transport sector subjects operating in «smart cities» has shown that branding, marketing and communication are important components of the sustainable urban transport mechanism based on the concept of «smart city» and municipal ecology. This is due to the following reasons:

1. Modernization of urban transport based on the concept of a «smart city» and municipal environmental management requires new methods of marketing support;

2. Consumer motivations for consumers of Ukrainian urban transport services depend on several factors that influence the level of demand for such services;

Cite as: Borysova, T., Monastyrskyi, G., Zielinska, A. \& Barczak, M. (2019). Innovation Activity Development of Urban Public Transport Service Providers: Multifactor Economic and Mathematical Model. Marketing and Management of Innovations, 4, 98-109. http://doi.org/10.21272/mmi.2019.4-08 
3. The concept of marketing provision should consider the organizational diversity of enterprises providing urban transport services and the size of the city, which requires the development of differentiated marketing approaches.

Therefore, in the context of the Transport Strategy of Ukraine until 2020, in terms of urban transport development, marketing functions can first be successfully implemented in formulating recommendations for marketing communication activities among consumers of urban transport services; recommendations on the evaluation of the effectiveness of marketing communication activities aimed at consumers of urban transport services; recommendations for forecasting the demand for transport services.

Literature Review. The results of the author's research confirmed the need for attention to the issues of urban transport development based on the principles of intelligent technologies in the marketing aspect. These issues are partly addressed in a series of projects by the Commission of the Council of Europe in support of energy-efficient transport, namely «A Direct Marketing Program for Public Transport (AD PERSONAM)», which lasted from 2008 to 2010, «Electric City Transport (ELE.C.TRA)», which lasted from 2013 to 2015, «Addressing Key Challenges of Sustainable Urban Mobility Planning (CH4LLENGE)», which lasted from 2013 until 2016.

The era of projects focused on the development of urban transport began in the 1960-1970s. The works (Smeed, 1961; Buchanan, et al., 1964; Leibbrand, 1970; Schaeffer, Sclar, 1975) emphasize the role of municipal transport in accelerated urban development. Significant contribution to the development of conceptual role of municipal transport in accelerated urban development was made by Smeed (outlined the traffic problem in town), Buchanan (explained the applied aspects of traffic in towns), Leibbrand (disclosed the questions of transportation and town planning), Schaeffer and Sclar (highlighted the organizational aspects of urban transportation models and urban growth).

But only in the 1990s scientists began to reflect on a more global idea - the creation of the liveable city, cost-effective, healthy in social terms and sustainable in the environmental sense. In this aspect, one can speak about municipal democracy, which is realized through the behaviour of key stakeholders in urbanization and transport development. Cronin \& Hightower (2004) explained an evaluation of the role of marketing in public transit organizations. Studies often focus on the problem of the relationship between public and private investment in urban transport infrastructure. Important influence to the development of transport management development was made by Poliak, et al. (outlined the place of financing public transport services from public funds in the transport system), Schubler, et al. (disclosed the question of the model-based estimation of private charging demand at public charging stations).

In studies of scientists were explained the application of micro-simulation at a large establishment and evaluating the impacts of urban freight traffic (Aditjandra et al., 2016), transportation demand management (Barcik, 2018). Analysis of the literature shows that the work of scientists focuses on customer, service quality and passenger satisfaction (Nunes, 2014; Krasnyanskiy, 2016; Umpleby, 2017; Walters, 2017; Huang, 2018; Morchadze, 2018), theoretical aspects of the sustainability in transportation (Krawiec, 2016; Tomanek, 2017; Lee, 2017; Currie, 2018), the role of intelligent technologies for efficient power supply in transport systems (Bosyi, 2017; Grabski, 2017). The high level of interest makes it profitable to use Modeling in transport management (Kii, 2014; Chauhan, 2016; Dolinayova, 2017; Hanumappa, 2018). In the studies of modern scientists, a lot of attention is paid to the influence of various factors of the external and internal environment on the urban transport policy.

In studies of scientists, there is a lack of attention to the efficiency of urban transport development and increase of its competitiveness. Only some works of researchers highlight some aspects of the municipal transport's functioning, which is associated with its influence on cities innovation, tourist attractiveness (Monastyrskyi, Borysova, 2018).

The analysis of the works of scholars allowed to distinguish the following factors that affect the innovativeness of the business entities of the services of urban public transport: marketing costs per year, 
environmental factor, financial potential, level of quality of service, level of management skills, the tariff for passenger transportation, market share.

The purpose of the study is to identify the vectors of the development of innovative activities of the subjects of the urban public transport services through multivariate analysis. The relevance of the study is related to the need to analyse the vectors of the development of Ukrainian cities on the principles of innovation, ecology and considering the needs of residents as services consumers. Particular attention is needed to the issue of urban transport as an important component of the city's infrastructure.

The purpose has determined the need to solve such problems as to develop an econometric model that would allow estimating and predicting the level of innovativeness depending on the indicators of ecology and marketing activities of transport service providers; to actualize the need to pay attention to the issues of urban transport development based on the principles of intellectual and environmental technologies; to provide a comparative analysis of the levels of innovation of public transport companies in Ukraine.

Methodology and research methods. To evaluate the influence of factor marks on the trait (innovation activity development of business entities providing urban public transport services) was proposed to apply multivariate correlation-regression analysis in the following sequence:

1) the selection of the most influential factors that are necessary for the construction of the model. The justification of the factors should be carried out with the help of expert appraisal;

2) construction of the regression structure, including all factors that have a significant impact on the resultant trait. At the same time, it is necessary to observe the conditions of absence of multicollinearity. If multicollinearity is found between factors, one of the pair of factor marks must be eliminated;

3 ) construction of the model in the form of a linear function using the estimation of parameters. To assess the tightness of the relationship between factors and the resultant indicator, the determination coefficient is calculated;

5) the model is checked for adequacy by the Fisher criterion;

6) to overcome the shortcomings of input information, autocorrelation is evaluated.

To evaluate the influence of several factor characteristics on the trait was used a multi-factor correlation-regression analysis that allowed obtaining an adequate model. In January-March 2018, the authors initiated a study on the current state of urban public transport in regional Ukrainian cities. Following this, the requests for public information were submitted by the Law of Ukraine «On Access to Public Information» to all city councils of Ukraine's regions except temporarily occupied territories.

The novelty of the article is the following: the results of the author's research confirmed the need for attention to the issues of urban transport development based on the principles of intellectual and ecological technologies; comparative analysis of levels of innovativeness of Ukrainian public transport companies is presented; adequate econometric model that shows the relationship between controllable factors and innovativeness is presented.

Results. Output data for conducting a correlation-regression analysis to determine the impact of factors on the innovativeness of business entities providing urban public transport services in Ukraine are given in Table 1. The study included a survey of 20 experts (marketers and experienced managers of transport companies) to determine weighting factors and the level of innovativeness through questionnaires. The expert evaluation was carried out using the marks method in accordance with the method described by (Shatteles, 1975; Klass, et al., 1978; Hrabovetskyy, 2010). The experts have evaluated each indicator of competitiveness. The data for correlation-regression analysis were provided by municipal utilities-providers of urban public transport services in such Ukrainian cities as (numbering is used in Table 1): 1 - Lviv; 2 - Sumy; 3 - Vinnytsia; 4 - Kharkiv; 5 - Ternopil; 6 - Uzhhorod; 7 - Dnipro; 8 - Lutsk; 9 - Kyiv; 10 - Khmelnytskyi. 
T. Borysova, G. Monastyrskyi, A. Zielinska \& M. Barczak. Innovation Activity Development of Urban Public Transport Service Providers: Multifactor Economic and Mathematical Model

Table 1. Output data for correlation-regression analysis

\begin{tabular}{|c|c|c|c|c|c|c|c|c|c|}
\hline 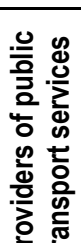 & 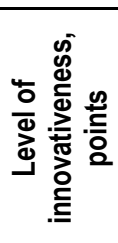 &  & 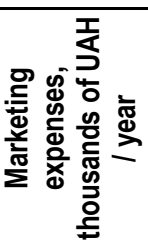 & 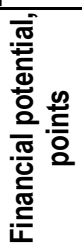 & 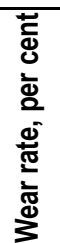 &  & 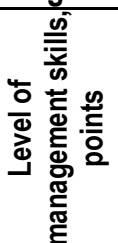 & 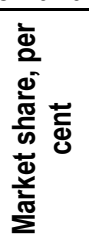 & 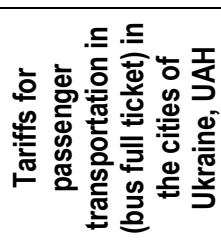 \\
\hline & $Y$ & $\boldsymbol{x}_{1}$ & $x_{2}$ & $x_{3}$ & $x_{4}$ & $x_{5}$ & $x_{6}$ & $x_{7}$ & $\boldsymbol{X}_{8}$ \\
\hline 1 & 9 & 3 & 8.6 & 8 & 25 & 9 & 6 & 55 & 5 \\
\hline 2 & 7 & 4 & 15 & 10 & 3 & 5 & 5 & 30 & 3 \\
\hline 3 & 7 & 4 & 3.5 & 4 & 45 & 5 & 7 & 20 & 3 \\
\hline 4 & 5 & 3 & 1.8 & 2 & 28 & 3 & 5 & 5 & 1 \\
\hline 5 & 5 & 5 & 15 & 3 & 35 & 5 & 5 & 6 & 5 \\
\hline 6 & 7 & 3 & 1.2 & 1 & 50 & 7 & 4 & 25 & 4.1 \\
\hline 7 & 5 & 2 & 3.2 & 3 & 45 & 4 & 4 & 15 & 3 \\
\hline 8 & 5 & 3 & 0.6 & 3 & 40 & 4 & 3 & 25 & 4 \\
\hline 9 & 8 & 2 & 7.5 & 5 & 0 & 7 & 9 & 32 & 6 \\
\hline 10 & 9 & 2 & 9 & 6 & 60 & 6 & 9 & 25 & 4 \\
\hline
\end{tabular}

Sources: developed by the authors based on (Letters, 2018).

The first stage in the estimation of the magnitude of the innovativeness of the economic entities providing urban public transport depending on the factors based on a multifactor mathematical model was the construction of the regression structure. To determine the significance of the factors influence, the correlation matrix $R_{y}(1)$ was used:

$$
R_{y}=\left(\begin{array}{ccccc}
r_{x_{1} x_{1}} & r_{x_{1} x_{2}} & \ldots & r_{x_{1} x_{m}} & r_{x_{1} y} \\
r_{x_{2} x_{1}} & r_{x_{2} x_{2}} & \ldots & r_{x_{2} x_{m}} & r_{x_{2} y} \\
\ldots & \ldots & \ldots & \ldots & \ldots \\
r_{x_{m} x_{1}} & r_{x_{m} x_{2}} & \ldots & r_{x_{m} x_{m}} & r_{x_{m} y} \\
r_{x_{1} y} & r_{x_{2} y} & \ldots & r_{x_{m} y} & r_{y y}
\end{array}\right)
$$

Using the statistics shown in Table 1, a correlation matrix $R_{y}$ was constructed.

$$
R_{y}=\left(\begin{array}{rrrrrrrrr}
1.000 & 0.462 & 0.060 & -0.115 & -0.157 & -0.310 & -0.264 & -0.065 & -0.046 \\
0.462 & 1.000 & 0.672 & -0.426 & 0.240 & 0.303 & 0.135 & 0.354 & 0.027 \\
0.060 & 0.672 & 1.000 & -0.515 & 0.390 & 0.357 & 0.643 & 0.189 & 0.059 \\
-0.115 & -0.426 & -0.515 & 1.000 & -0.149 & -0.143 & -0.293 & -0.199 & -0.009 \\
-0.157 & 0.240 & 0.390 & -0.149 & 1.000 & 0.410 & 0.828 & 0.720 & 0.082 \\
-0.310 & 0.303 & 0.357 & -0.143 & 0.410 & 1.000 & 0.250 & 0.356 & 0.073 \\
-0.264 & 0.135 & 0.643 & -0.293 & 0.828 & 0.250 & 1.000 & 0.514 & 0.077 \\
-0.065 & 0.354 & 0.189 & -0.199 & 0.720 & 0.356 & 0.514 & 1.000 & 0.046 \\
-0.046 & 0.027 & 0.059 & -0.009 & 0.082 & 0.073 & 0.077 & 0.046 & 1.000
\end{array}\right)
$$

The values of this matrix indicate that the factors $x_{2}$ (marketing expenses) and $x_{4}$ (wear rate) have a negligible impact on the resultant sign (level of innovativeness) since the correlation coefficients are respectively 0.027 and 0.009 . Consequently, they cannot be considered. 

Service Providers: Multifactor Economic and Mathematical Model

Using Farrar-Globard method to determine the presence of multicollinearity for the remaining factors, the following calculations were made using formulas in accordance with (Yeleyko, 1995):

$$
\chi_{p}^{2}=-\left(n-1-\frac{2 m+5}{6}\right) \ln (\operatorname{det} R),
$$

where $n$ - sample size; $m$ - number of factors; det $R$ - determinant of the correlation matrix; $R$ correlation matrix of the form (3):

$$
R=\left[\begin{array}{cccc}
r_{x_{1} x_{1}} & r_{x_{1} x_{2}} & \ldots & r_{x_{1} x_{m}} \\
r_{x_{2} x_{1}} & r_{x_{2} x_{2}} & \ldots & r_{x_{2} x_{m}} \\
\ldots & \ldots & \ldots & \ldots \\
r_{x_{m} x_{1}} & r_{x_{m} x_{2}} & \ldots & r_{x_{m} x_{m}}
\end{array}\right] .
$$

The next stage was to construct the correlation matrix $R$ for factors $x_{1}$ (environmental factor), $x_{3}$ (financial potential), $x_{5}$ (level of quality of service), $x_{6}$ (level of management skills), $x_{7}$ (market share) and $x_{8}$ (tariff for passenger transportation).

$$
\mathrm{R}=\left(\begin{array}{rrrrrr}
1,000 & 0,060 & -0,157 & -0,310 & -0,264 & -0,065 \\
0,060 & 1,000 & 0,390 & 0,357 & 0,643 & 0,189 \\
-0,157 & 0,390 & 1,000 & 0,410 & 0,828 & 0,720 \\
-0,310 & 0,357 & 0,410 & 1,000 & 0,250 & 0,356 \\
-0,264 & 0,643 & 0,828 & 0,250 & 1,000 & 0,514 \\
-0,065 & 0,189 & 0,720 & 0,356 & 0,514 & 1,000
\end{array}\right)
$$

For the study, $X \rho^{2}$ is determined by the formula (2), det $\mathrm{R}$ is equal to 0.0246195 . Received:

$$
\chi_{p}^{2}=-\left(10-1-\frac{2 \times 6+5}{6}\right) \ln (0.0246195)=22.842654 .
$$

With a given probability $p=0.9$ and the number of degrees of freedom $k=15$, was found a table value $X T^{2}=22.3$. Since $X T^{2}<X p^{2}$, then with a reliability of 0.9 , it can be assumed that there is general multicollinearity.

To determine the factors between which there is multicollinearity, $t$-statistics was used in accordance with (Feshchur, et al., 2003), which involves the construction of the matrix Z, reversed to the correlation (4):

$$
Z=R^{-1}=\left[\begin{array}{cccc}
Z_{11} & z_{12} & \ldots & z_{1 m} \\
Z_{21} & z_{22} & \ldots & z_{2 m} \\
\ldots & \ldots & \ldots & \ldots \\
Z_{m 1} & z_{m 2} & \ldots & z_{m m}
\end{array}\right]
$$

The matrix $Z$ has the following form:

$$
Z=\left(\begin{array}{rrrrrr}
1.968 & -1.693 & -1.814 & 1.303 & 2.883 & -0.192 \\
-1.693 & 3.848 & 3.094 & -1.979 & -5.132 & 0.278 \\
-1.814 & 3.094 & 8.163 & -2.458 & -7.724 & -1.736 \\
1.303 & -1.979 & -2.458 & 2.415 & 3.187 & -0.269 \\
2.883 & -5.132 & -7.724 & 3.187 & 10.589 & 0.141 \\
-0.192 & 0.278 & -1.736 & -0.269 & 0.141 & 2.208
\end{array}\right)
$$


T. Borysova, G. Monastyrskyi, A. Zielinska \& M. Barczak. Innovation Activity Development of Urban Public Transport Service Providers: Multifactor Economic and Mathematical Model

Subsequently, partial correlation coefficients of formula (5) were found which allowed the characterization of the tightness of the relationship between the two variables, provided that other variables do not affect this relationship:

where $z_{i j}, z_{i i}, z_{i j}$ are the elements of the matrix $Z$

$$
r_{i j .12 . . m}=\frac{-z_{i j}}{\sqrt{z_{i i} z_{j j}}}
$$

Table 2 shows the obtained partial correlation coefficients.

Table 2. Partial coefficients of correlation

\begin{tabular}{|c|c|c|c|c|c|c|}
\hline \multirow{2}{*}{ Factors } & \multicolumn{7}{|c|}{ Factors } \\
\cline { 2 - 7 } & 1 & 3 & 5 & 6 & 7 & 8 \\
\hline 1 & $\mathrm{X}$ & -0.615 & -0.453 & 0.598 & 0.632 & -0.092 \\
\hline 3 & $\mathrm{X}$ & $\mathrm{X}$ & 0.552 & -0.649 & -0.804 & 0.095 \\
\hline 5 & $\mathrm{X}$ & $\mathrm{X}$ & $\mathrm{X}$ & -0.554 & -0.831 & -0.409 \\
\hline 6 & $\mathrm{X}$ & $\mathrm{X}$ & $\mathrm{X}$ & $\mathrm{X}$ & 0.630 & -0.117 \\
\hline 7 & $\mathrm{X}$ & $\mathrm{X}$ & $\mathrm{X}$ & $\mathrm{X}$ & $\mathrm{X}$ & 0.029 \\
\hline 8 & $\mathrm{X}$ & $\mathrm{X}$ & $\mathrm{X}$ & $\mathrm{X}$ & $\mathrm{X}$ & $\mathrm{X}$ \\
\hline
\end{tabular}

Sources: developed by the authors based on (Letters, 2018).

After that, t-statistics for the partial coefficients in table 2 was obtained by the formula (6) according to the method described by (Yeleyko, 1995):

$$
t_{i j}=\frac{r_{i j .12 . m} \sqrt{n-m-1}}{\sqrt{1-r^{2} i j .12 . . m}} .
$$

Table 3 shows the results of the definition of $t$-statistics.

Table 3. Definition of t-statistics

\begin{tabular}{|c|c|c|c|c|c|c|}
\hline \multirow{2}{*}{ Factors } & \multicolumn{7}{|c|}{ Factors } \\
\cline { 2 - 7 } & $\mathrm{X}$ & 3 & 5 & 6 & 7 & 8 \\
\hline 1 & $\mathrm{X}$ & -1.351 & -0.879 & 1.292 & 1.411 & -0.161 \\
\hline 3 & $\mathrm{X}$ & $\mathrm{X}$ & 1.147 & -1.479 & -2.342 & 0.166 \\
\hline 5 & $\mathrm{X}$ & $\mathrm{X}$ & $\mathrm{X}$ & -1.152 & -2.585 & -0.776 \\
\hline 6 & $\mathrm{X}$ & $\mathrm{X}$ & $\mathrm{X}$ & $\mathrm{X}$ & 1.406 & -0.203 \\
\hline 7 & $\mathrm{X}$ & $\mathrm{X}$ & $\mathrm{X}$ & $\mathrm{X}$ & $\mathrm{X}$ & 0.051 \\
\hline 8 & $\mathrm{X}$ & $\mathrm{X}$ & $\mathrm{X}$ & $\mathrm{X}$ & $\mathrm{X}$ & $\mathrm{X}$ \\
\hline
\end{tabular}

Sources: developed by the authors based on (Letters, 2018).

Next, for a given confidence probability $p$ and degrees of freedom $k=n-m-1$, was found the critical value of Student's criterion $t_{c r}$ in the table in accordance with (Feshchur, et al., 2003). It is known that if $\left|t_{i j}\right|>$ $t_{c r}$, then with reliability $p$ it can be argued that there is multicollinearity between the factors $x_{i}$ and $x_{j}$. Received:

$$
\begin{aligned}
& r_{13.5678}=-0,615, \quad t_{13}=-1,351 ; r_{15.3678}=-0,453, t_{15}=-0,879 \\
& r_{16.3578}=0,598, \quad t_{16}=1,292 ; r_{17.3578}=0,632, t_{17}=1,411 \\
& r_{18.3567}=-0,092, \quad t_{18}=-0,161 ; r_{35.1678}=0,552, \quad t_{35}=1,147
\end{aligned}
$$




$$
\begin{aligned}
& r_{36.1578}=-0,649, \quad t_{36}=-1,479 ; r_{37.1568}=-0,804, t_{37}=-2,342 ; \\
& r_{38.1567}=0,095, \quad t_{38}=0,166 ; r_{56.1378}=-0,554, \quad t_{56}=-1,152 ; \\
& r_{57.1368}=-0,831, \quad t_{57}=-2,585 ; r_{58.1367}=-0,409, t_{58}=-0,776 ; \\
& r_{67.1358}=0,630, \quad t_{67}=1,406 ; r_{68.1357}=-0,117, \quad t_{68}=-0,203 ; \\
& r_{78.1356}=0,029, \quad t_{78}=0,051 .
\end{aligned}
$$

For degrees of freedom, $k=10-6-1=3$ and the probabilities $p=0.9$, the value $t_{c i}=2.353$. Consequently, considering the results of the research, it can be concluded that there is multicollinearity between the factors $x_{5}$ (level of quality of service) and $x_{7}$ (market share). To eliminate multicollinearity, one of a couple of factors must be eliminated. It is worthwhile to exclude $x_{7}$ (market share), as there is already a more significant factor - the level of quality of service.

To evaluate the parameters of the regression model, the least-squares method is used, the essence of which is to find the theoretical line that exactly aligns the statistical series. Mathematically this takes on the following form (7):

$$
\sum_{i=1}^{n}\left(y_{i}-\hat{y}_{i}\right)^{2} \rightarrow \min .
$$

The model is represented as a linear function (8). The parameters of this model are calculated by the formula (9).

$$
\begin{gathered}
\hat{y}=a_{0}+a_{1} \times x_{1}+a_{2} x_{4}+a_{3} x_{5}+a_{4} x_{6}+a_{5} x_{8} . \\
\vec{A}=\left(X^{T} X\right)^{-1} X^{T} \vec{Y},
\end{gathered}
$$

where $\vec{A}$ - vector of model parameters; $X$ - matrix of statistical data of factors; $\vec{Y}$-vector of statistics of the indicator.

The matrix of statistical data of the factors is presented below:

$$
X=\left(\begin{array}{cccccc}
1 & 3 & 8 & 9 & 6 & 5 \\
1 & 4 & 10 & 5 & 5 & 3 \\
1 & 4 & 4 & 5 & 7 & 3 \\
1 & 3 & 2 & 3 & 5 & 1 \\
1 & 5 & 3 & 5 & 5 & 5 \\
1 & 3 & 1 & 7 & 4 & 4.1 \\
1 & 2 & 3 & 4 & 4 & 3 \\
1 & 3 & 3 & 4 & 3 & 4 \\
1 & 2 & 5 & 7 & 9 & 6 \\
1 & 2 & 6 & 6 & 9 & 4
\end{array}\right)
$$

Then the matrix $X^{\top}$ is the following:

$$
X^{\top}=\left(\begin{array}{rrrrrrrrrr}
1 & 1 & 1 & 1 & 1 & 1 & 1 & 1 & 1 & 1 \\
3 & 4 & 4 & 3 & 5 & 3 & 2 & 3 & 2 & 2 \\
8 & 10 & 4 & 2 & 3 & 1 & 3 & 3 & 5 & 6 \\
9 & 5 & 5 & 3 & 5 & 7 & 4 & 4 & 7 & 6 \\
6 & 5 & 7 & 5 & 5 & 4 & 4 & 3 & 9 & 9 \\
5 & 3 & 3 & 1 & 5 & 4.1 & 3 & 4 & 6 & 4
\end{array}\right)
$$


The product of the matrix $X^{\top} X$ is presented below:

$X^{\top} X=\left(\begin{array}{rrrrrr}10 & 31 & 45 & 55 & 57 & 38.1 \\ 31 & 105 & 141 & 168 & 171 & 117.3 \\ 45 & 141 & 273 & 265 & 275 & 178.1 \\ 55 & 168 & 265 & 331 & 327 & 225.7 \\ 57 & 171 & 275 & 327 & 363 & 226.4 \\ 38.1 & 117.3 & 178.1 & 225.7 & 226.4 & 162.81\end{array}\right) \begin{array}{r}X^{\top} Y \\ 67 \\ 325 \\ 391 \\ 404 \\ 266.7\end{array}$

Then the inverse matrix $\left(X^{\top} X\right)^{-1}$ got the following form:

$$
\left(X^{\top} X\right)^{-1}=\left(\begin{array}{rrrrrr}
3.561 & -0.523 & 0.040 & -0.179 & -0.185 & 0.005 \\
-0.523 & 0.133 & -0.012 & 0.018 & 0.024 & -0.018 \\
0.040 & -0.012 & 0.019 & -0.014 & -0.008 & 0.010 \\
-0.179 & 0.018 & -0.014 & 0.089 & -0.004 & -0.073 \\
-0.185 & 0.024 & -0.008 & -0.004 & 0.038 & -0.012 \\
0.005 & -0.018 & 0.010 & -0.073 & -0.012 & 0.125
\end{array}\right)
$$

The following estimates of model parameters are obtained:

$a_{0}=2.043 ; a_{1}=-0.182 ; a_{2}=0.1102 ; a_{3}=0.6493 ; a_{4}=0.3074 ; a_{5}=-0.157$

Using the obtained values of the parameters of the model was constructed the proper econometric model (10) by the formula (8):

$$
y=2.043-0.182 x_{1}+0.1102 x_{3}+0.6493 x_{5}+0.3074 x_{6}-0.157 x_{8} .
$$

To estimate the tightness of the relationship between the factors and the indicator allowed the determination coefficient, which is calculated by the formula (11) in accordance with (Feshchur, et al., 2003):

$$
R^{2}=\frac{\sum\left(\hat{y}_{i}-\bar{y}\right)^{2}}{\sum\left(y_{i}-\bar{y}\right)^{2}}
$$

where $\bar{y}$ - the average value; $y_{i}$ - actual values of the $i$-th observation; $\hat{y}_{i}$ - theoretical values of the $i$ th observation.

In this case, the determination coefficient was:

$$
R^{2}=\frac{22.91}{24.1}=0.95
$$

Thus, the calculations allowed to conclude that there is a close relationship between the performance indicator (the level of the innovativeness) and the factors that affect it (environmental factor, financial potential, level of quality of service, level of management skills, the tariff for passenger transportation).

In assessing the adequacy of the econometric model with statistical data, was used Fisher criterion (12) in accordance with (Feshchur, et al., 2003): 
T. Borysova, G. Monastyrskyi, A. Zielinska \& M. Barczak. Innovation Activity Development of Urban Public Transport Service Providers: Multifactor Economic and Mathematical Model

$$
F_{C}=\frac{\sum\left(\hat{y}_{i}-\bar{y}\right)^{2} / m}{\sum\left(y_{i}-\hat{y}_{i}\right)^{2} /(n-m-1)}=\frac{R^{2}}{1-R^{2}} \times \frac{n-m-1}{m}
$$

where $m$ - the number of factors in the equation on which depends; $n$ - number of observations.

Calculated value $F_{c}$ :

$$
F_{c}=\frac{0.95}{1-0.95} \times \frac{10-5-1}{5}=15.36
$$

With a given probability $p=0.95$ and several degrees of freedom, $k_{1}=m=5$ i $k_{2}=n-m-1=4$, the tabular value of $F$ is found. Since $F=6.26<F_{c}$, it can be asserted with reliability 0.95 , that the built econometric model is adequate to the statistical data of the general population. The next step was to test the econometric model for the presence of autocorrelation, which may necessitate the introduction of a new factor into the model. Such a situation may occur in the case of a wrongly chosen model for describing an economic process or a lack of statistical basis for building an econometric model. To estimate the autocorrelation of the residues (deviations), the coefficient of autocorrelation (13) is used in accordance with (Leshchynskyy, et al., 2003):

$$
\rho=\frac{\sum_{i=1}^{n} u_{i} u_{i-1}}{\sum_{i=1}^{n} u_{i}^{2}}
$$

where $u_{t}=y_{t}-\hat{y}_{t}-$ the remnants (deviations).

It is known that in the absence of autocorrelation $\rho \approx 0$, with a positive autocorrelation $\rho \rightarrow 1$, and with negative autocorrelation $\rho \rightarrow-1$.

Table 4. Intermediate calculations to determine the adequacy of the model

\begin{tabular}{|c|c|c|c|c|c|c|}
\hline $\begin{array}{c}\text { Significance } \\
\text { value }\end{array}$ & \multicolumn{6}{|c|}{ The value of the intermediate indicators to determine the adequacy of the model } \\
\hline$y$ & $\left(y-y_{c}\right)^{2}$ & $y_{m}$ & $\left(y_{m}-y_{c}\right)^{2}$ & $u=y-y_{m}$ & $u_{i} u_{i-1}$ & $u^{2}$ \\
\hline 9 & 5.290 & 9.285 & 6.685 & -0.285 & $X$ & 0.081 \\
\hline 7 & 0.090 & 6.915 & 0.046 & 0.085 & -0.024 & 0.007 \\
\hline 7 & 0.090 & 6.823 & 0.015 & 0.177 & 0.015 & 0.031 \\
\hline 5 & 2.890 & 5.360 & 1.794 & -0.360 & -0.064 & 0.130 \\
\hline 5 & 2.890 & 5.220 & 2.189 & -0.220 & 0.079 & 0.049 \\
\hline 7 & 0.090 & 6.670 & 0.001 & 0.330 & -0.073 & 0.109 \\
\hline 5 & 2.890 & 5.375 & 1.755 & -0.375 & -0.124 & 0.141 \\
\hline 5 & 2.890 & 4.549 & 4.628 & 0.451 & -0.169 & 0.204 \\
\hline 9 & 5.290 & 8.361 & 2.757 & 0.639 & 0.289 & 0.409 \\
\hline 8 & 1.690 & 8.442 & 3.036 & -0.442 & -0.283 & 0.196 \\
\hline
\end{tabular}

Sources: developed by the authors based on (Letters, 2018)

Based on the calculations presented in Table 4, was received:

$$
\rho=\frac{-0.35}{1.36}=-0.261
$$

Therefore, was asserting that in this case autocorrelation is insignificant, and the resulting econometric model (10), which reflects the relationship between managed factors and innovativeness, is adequate.

Conclusions. Modern management paradigm considers business entities as open systems, the innovativeness of which depends on many factors. However, with any combination of factors in the market 
of urban public transport services, the result is important, which can acquire different socio-economic content and innovativeness. The basic principle of marketing of entities is the targeting of the result of the activity - the innovativeness. The goals of all functional areas of organization management, including marketing, should be subordinated to the goals of the system - to obtain the innovativeness. The research has shown that the size of the innovativeness of providers of public transport services can be successfully interpreted through functional and statistical dependencies, which reflect the general and individual laws of the development of such entities using multi-factor mathematical models. The obtained econometric model, which reflects the relationship between managed factors and the innovativeness, is adequate and can be used to predict the innovation contribution of domestic providers of urban public transport services to the community.

Author Contributions: Conceptualization, T.B. and A.Z.; methodology, T. B.; software, T. B.; validation, T. B., M. B. and G.M.; formal analysis, T. B. and A. Z.; investigation, T.B.; resources, T. B. and M. B.; data curation, T. B.; writing-original draft preparation, T. B.; writing-review and editing, T. B.; visualization, T. B.; supervision, G. M.; project administration, G.M.

Funding: This research received external funding. The authors express their gratitude to the Ministry of Education and Science of Ukraine, with the support of which an article was published in the framework of the scientific work of young scientists on the topic: «Formation of the mechanism of sustainable urban transport development based on the concept of «smart» city and municipal ecological logistics» (state registration number 0117U003871).

\section{References}

Aditjandra P., Galatioto, F., Bell, M., \& Zunder, T. (2016). Evaluating the Impacts of Urban Freight Traffic: Application of Microsimulation at a Large Establishment. EJTIR, 16(1), 4-22. Retrieved from https://www.tudelft.nl/en/tpm/about-thefaculty/departments/engineering-systems-and-services/research/ejtir/back-issues/volume16-2016.

Barcik, R., \& Bylinko, L. (2018). Transportation Demand Management as a Tool of Transport Policy. Transport Problems, 13(2), 121-131. DOI:10.20858/tp.2018.13.2.12.

Bosyi, D., Sablin, O., Khomenko, I., Kosariev, Y., Kebal, I., \& Myamlin, S. J. (2017). Intelligent Technologies for Efficient Power Supply in Transport Systems. Transport Problems, 12 (Special Edition), 57-70. doi:10.20858/tp.2017.12.se.5.

Buchanan, C., et al. (1964). Traffic in Towns. London UK: HMSO.

Chauhan, V., Suman, H.K., \& Bolia, N.B. (2016). Binary Logistic Model for Estimation of Mode Shift into Delhi Metro. The Open Transportation Journal, 10, 124-136. DOI:10.2174/18744447801610010124.

Cronin, J. J., \& Hightower, R. J. (2004). An Evaluation of the Role of Marketing in Public Transit Organizations. Journal of Public Transportation,7(2). Retrieved August 20, 2018, from https://www.nctr.usf.edu/jpt/pdf/JPT 7-2 Hightower.pdf.

Currie, G., \& Gruyter, C.D. (2018). Exploring Links between the Sustainability Performance of Urban Public Transport and Land Use in International Cities. The Journal of Transport and Land Use, 11(1), 325-342. http://dx.doi.org/10.5198/jtlu.2018.957.

Dolinayova, A., Camaj, J., \& Kanis, J. (2017). Charging Railway Infrastructure Models and Their Impact to Competitiveness of

Railway Transport. Transport Problems, 12(1), 139-150. DOI:10.20858/tp.2017.12.13.

Everitt, V. (2017). Capitalising on emerging data. Eurotransport,15(2), 27.

Feshchur, R., Barvinskyy, A., \& Kichor, V. (2003). Statistics: Theoretical Aspects and Applied Aspects. Lviv: Intelekt-Zahid.

Grabski, W., \& Daszczuk, W.D. (2017). A Study on Cooperation of Urban Transport Means: PRT and Light Rail. Transport

Problems, 12(4), 5-14. DOI:10.20858/tp.2017.12.4.1.

Hanumappa, D., Mulangi, R.H., \& Kudachimath, N.S. (2018). Traffic Characteristics Evaluation and Traffic Management

Measures: A Case study of Dharwad City. The Open Transportation Journal, 12, 258-272. DOI: 10.2174/1874447801812010258. Hrabovetskyy, B. (2010). Methods of Expert Assessments: Theory, Methodology, Directions of Use: Monograph. Vinnytsya: VNTU.

Huang, W., \& Shuai, B. (2018). A Methodology for Calculating the Passenger Comfort Benefits of Railway Travel. Journal of Modern Transportation, 26(2), 107-118. doi:https://doi.org/10.1007/s40534-018-0157-y.

Kii, M., Akimoto, K., \& Doi, K. (2014). Measuring the Impact of Urban Policies on Transportation Energy Saving Using a Land Use-transport Model. ATSS Research, 37, 98-109. http://dx.doi.org/10.1016/j.iatssr.2014.03.002.

Klass, A., Heryky, K., Kolen, Y., \& Shuyan, Y. (1978). Introduction to Econometric Modeling. Moskow: Statystyka.

Krasnyanskiy, M., \& Penshin, N. (2016). Quality Criteria when Assessing Competitiveness in Road Transport Services. Transport Problems, 11(4), 15-20. DOI:10.20858/tp.2016.11.4.2. 
T. Borysova, G. Monastyrskyi, A. Zielinska \& M. Barczak. Innovation Activity Development of Urban Public Transport Service Providers: Multifactor Economic and Mathematical Model

Krawiec, S., Łazarz, B., Markusik, S., Karoń, G., Sierpiński, G., \& Krawiec, K. (2016). Urban Public Transport with the Use of Electric Buses - Development Tendencies. Transport Problems, 11(4), 127-137. DOI:10.20858/tp.2016.11.4.12.

Lee, H.K., \& Kim, H.Y. (2017). A Crossing-Line Between Transportation Evaluation and Natural Capital Assessment: Perspectives on Ecological Economics and Project Evaluation. The Open Transportation Journal, 11, 44-52.

Leibbrand, K. (1970). Transportation and Town Planning. Cambridge, MA: MIT Press.

Leshchynskyy, O.L., Ryazantseva, V.V., \& Yunkova, O.O. (2003). Econometriya. Kyiv: MAUP

Letter from Khmelnytsky City Council No. 12-0986-02-18 dated March 21, 2018.

Letter from the Dnipro City Council No. 5 / 3-339 dated March 27, 2018.

Letter from the Kharkiv City Council No. 55 / 0 / 188-18 dated March 27, 2018.

Letter from the Kyiv City Council (Kyiv City State Administration) No. 053-1707 dated March 02, 2018.

Letter from the Lutsk City Council No. 0-26 / 198 dated March 23, 2018.

Letter from the Lviv City Council No. 2503-877 dated March 7, 2018.

Letter from the Sumy City Council No. 98 / 03.02.03-02 dated March 22, 2018.

Letter from the Ternopil City Council No. 955 / 01-10 dated March 27, 2018.

Letter from the Uzhgorod City Council No. 115 / 03-23 dated March 14, 2018.

Letter from the Vinnytsia City Council No. 01-00-019-13316 dated March 26, 2018.

Mochalin, S., \& Kasper, M. (2017). Condition for Application of Logistic Principles in Practice of Urban Public Passenger

Transport in the City of Omsk. Transport Problems, 12 (Special Edition), 71-86. doi:10.20858/tp.2017.12.se.6.

Monastyrskyi, G., \& Borysova, T. (2018). Marketing Innovation Activity of Urban Public Transport: Results of the Empirical

Study. Marketing and Management of Innovations, 3, 229-240.

Morchadze, T., \& Rusadze, N. (2018). Ways to Address the Challenges in Passenger Traffic within the Urban Transport Systems. Transport Problems, 13(3), 65-77. DOI:10.20858/tp.2018.13.3.6.

Nemtinov, V., Nemtinova, Y., Borisenko, A., \& Mokrozub, V. (2017). Information Support of Decision Making in Urban Passenger Transport Management. Transport Problems, 12(4), 83-90. DOI:10.20858/tp.2017.12.4.8.

Nunes, A. A., Galvao, T., \& Cunha, J. F. (2014). Urban public transport service co-creation: Leveraging passenger's knowledge to enhance travel experience. Procedia-Social and Behavioral Sciences,(111), 577-585.

Poliak, M., Semanova, S.M., Komackova, L., Simurkova, P., \& Mrníkova, M. (2017). Financing Public Transport Services from

Public Funds. Transport Problems, 12(4), 61-72. doi:10.20858/tp.2017.12.4.6.

Public Transport Trends 2017. (n.d.). Retrieved August 20, 2018, from URL: http://www.uitp.org/public-transport-trends.

Schaeffer, K.H., \& Sclar E. (1975). Access for All: Transportation and Urban Growth. Harmondsworth, UK: Penguin.

Schubler, M., Niels, T., \& Bogenberger, K. (2017). Model-based Estimation of Private Charging Demand at Public Charging

Stations. EJTIR, 17(1), 153-169. Retrieved from https://d1rkab7tlqy5f1.cloudfront.net/TBM/Over faculteit/Afdelingen/Engineering

Systems and Services/EJTIR/Back issues/17.1/2017_01a_02 Model-based estimation of private charging.pdf.

Shatteles, T. (1975). Modern Economic Methods. Moskow: Statystyka.

Smeed, R.J. (1961). The Traffic Problem in Town. Manchester, England.

Spiekermann, K., \& Wegener, M. (2018). Multi-level Urban Models: Integration Across Space, Time and Policies. The Journal

of Transport and Land Use, 11(1), 67-81. http://dx.doi.org/10.5198/ttlu.2018.1185.

Tomanek, R. (2017). Free-fare Public Transport in the Concept of Sustainable Urban Mobility. Transport Problems, 12 (Special

Edition), 95-105. doi:10.20858/tp.2017.12.se.8.

Umpleby, G. (2017). How passenger information contributes to passenger satisfaction. Eurotransport,15(4), 17-19

Walters, C. (2017). The voice of today's passenger. Eurotransport, 15(1), 8-9.

Yeleyko, V.I. (1995). Fundamentals of Econometrics. Lviv: Marka LTD.

T. М. Борисова, д.е.н., доцент, Тернопільський національний економічний університет (Україна);

Г. Л. Монастирський, д.е.н., професор, Тернопільський національний економічний університет (Україна);

A. Зелінська, D.Sc, професор, Вроцлавський економічний університет (Польща);

M. Барчак, Ph.D., доцент, Університет економіки в Бидгощі (Польща).

Розвиток інноваційної діяльності надавачів послуг міського громадського транспорту: багатофакторна

економіко-математична модель

у статті обгрунтовано, що серед фракторів, які впливають на інноваційність українських постачальників послуг міського громадського транспорту, можна виокремити екологічність транспортних засобів, рівень маркетингових витрат, фрінансовий потенціал, рівень зносу транспортних засобів, рівень якості обслуговування, рівень управлінських навичок, частка ринку, величина тарифру на пасажирські перевезення. Систематизація літературних джерел та підходів до вирішення проблеми якості транспортних послуг засвідчила, що рівень інноваційності постачальників послуг міського громадського транспорту можна успішно інтерпретувати через фуннкціональні та статистичні залежності, які відображають загальні та індивідуальні закони розвитку таких суб'єктів, зокрема, використовуючи багатофракторні математичні моделі. Основною метою проведеного дослідження $\epsilon$ визначення иляхів підвищення інноваційності 
T. Borysova, G. Monastyrskyi, A. Zielinska \& M. Barczak. Innovation Activity Development of Urban Public Transport Service Providers: Multifactor Economic and Mathematical Model

надавачів послуг міського громадського транспорту обласних иентрів України. Завданням дослідження $є$ оцінка впливу низки фракторних змінних на результуючу ознаку з використанням багатофракторного регресійного аналізу, що дозволив отримати адекватну модель. У статті представлено результати оцінки інноваційності українських постачальників послуг міського громадського транспорту на основі математичної багатоффакторної моделі. У січні-березні 2018 p. автори ініціювали дослідження сучасного стану міського громадського транспорту в містах обласного значення України. Методичним інструментарієм проведеного дослідження стали метод регресійно-кореляційного аналізу, економіко-математичне моделювання, опитування через запити на доступ до публічної інформації відповідно до Закону України «Про доступ до публічної інфоормації», які були надіслані до всіх міських рад реаіонів України, за винятком тимчасово окупованих територій. Дослідження включало опитування 20 експертів (маркетологів та досвідчених менеджерів транспортних компаній) для визначення вагових коесріцієнтів та рівня інноваційності за допомогою анкет. Оцінювання проводили з використанням методу експертних оцінок. Отримана економетрична модель була перевірена на адекватність за критерієм Фішера та на наявність автокореляиії. Доведено, що такими керованими факторами є екологічність транспортних засобів, фінансовий потенціал, рівень якості обслуговування, рівень управлінських навичок, тариф на пасажирські перевезення. Модель може бути використана для прогнозування впливу керованих фракторів на рівень інноваційності постачальників послуг міського громадського транспорту. Результати проведеного дослідження можуть бути корисними для аспірантів, науковиів, що досліджують питання інноваційної діяльності громадського транспорту та публічного управління, менеджерів сфери міського громадського транспорту України.

Ключові слова: економетрична модель, екологістика, інноваційність, міський транспорт, фактори інноваційності.

Manuscript received: 13.07.2019.

(C) The author(s) 2019. This article is published with open access at Sumy State University. 